\title{
EVALUASI TATA KELOLA TEKNOLOGI INFORMASI DI FUNGSI ICT PT XYZ MENGGUNAKAN FRAMEWORK COBIT 5 PADA DOMAIN PROSES BAI06 MENGELOLA PROGRAM DAN PROYEK
}

\author{
Adilla Ayin Filladelfia Simangunsong ${ }^{1 *}$, Lovinta Happy Atrinawati ${ }^{1}$ \\ ${ }^{1}$ Prodi SISTEM INFORMASI , Jurusan MATEMATIKA DAN TEKNOLOGI INFORMASI, \\ Institut Teknologi Kalimantan \\ Jl Soekarno Hatta KM 15, Balikpapan, Kalimantan Timur, 76127
}

\begin{abstract}
Abstrak
PT. XYZ merupakan perusahaan yang menyelenggarakan kegiatan usaha di sektor hulu bidang minyak dan gas bumi, yang meliputi eksplorasi dan eksploitasi dan memanfaatkan penerapan Teknologi Informasi (TI) di setiap wilayah kerja dalam mengoptimalkan pengelolaan, kinerja dan kemajuan perusahaan. PT XYZ telah melakukan penerapan Tata Kelola Teknologi Informasi menggunakan Framework COBIT 4.1. Namun tidak ada dilakukannya evaluasi Tata Kelola TI yang sudah dijalankan selama 3 tahun perusahaan beroperasi, oleh karena itu sangat perlu untuk dilakukannya evaluasi dan penilaian Tata Kelola TI di perusahaan. Penelitian pada kali ini bertujuan untuk mengukur tingkat kapabilitas pada Tata Kelola TI di PT XYZ dengan menggunakan Process Assesment Model (PAM) COBIT 5, dengan menggunakan data primer yaitu data wawancara serta data sekunder melalui pengamatan lingkungan kerja dan dokumen organisasi. Berdasakan hasil dari penelitian serta kesepakatan pihak perusahaan proses domain yang akan diukur adalah proses BAIO1 Mengelola Program dan Proyek. Hasil pegukuran tingakat kapabilitas pada proses BAIO1 Mengelola Program dan Proyek adalah berada pada level 2 (managed process). Rekomendasi serta langkah perbaikan diberikan sesuai best practice dan kriteria untuk memenuhi tingkat kapabilitas sesuai Framework COBIT 5.
\end{abstract}

Kata kunci: Evaluasi, Tata Kelola, COBIT

\section{PENDAHULUAN}

Dalam suatu lingkungan yang telah memanfaatkan penerapan Teknologi Informasi (TI), tata kelola TI merupakan hal penting yang perlu untuk diperhatikan. Pengelolaan dan perencanaan TI yang baik dapat memberikan solusi TI dengan kualitas yang baik, tepat waktu dan sesuai dengan anggaran yang telah direncanakan. Penerapan tata kelola TI yang benar bagi suatu perusahaan dapat meningkatkan efisensi, produktifitas dan meminimalisir risiko yang ada dengan tepat, sehingga adanya tata kelola TI sangatlah penting dalam mendukung kesuksesan bisnis bagi suatu perusahaan.

PT. XYZ Asset 5 merupakan perusahaan yang menyelenggarakan kegiatan usaha di sektor hulu bidang minyak dan gas bumi, yang meliputi eksplorasi dan eksploitasi. Wilayah kerja XYZ terbagi ke dalam lima asset yang terbagi kedalam 21 Field. Dalam melakukan kegiatan usahanya, PT XYZ memiliki visi yaitu, "Menjadi perusahaan eksplorasi dan produksi minyak dan gas bumi kelas dunia tahun 2014 hingga 2025". Untuk mencapai visi dari perusahaan, salah satu hal yang dilakukan oleh perusahaan adalah memanfaatkan penerapan TI di setiap wilayah kerja dalam mengoptimalkan pengelolaan, kinerja dan kemajuan perusahaan. Oleh karena itu perlu dilakukan pengelolaan TI yang baik dan benar, sehingga keberadaan TI dapat dirasakan manfaatnya oleh perusahaan. Salah satu solusinya yaitu dengan menerapkan Tata Kelola TI dalam mengimplementasikan, mereview, mengadministrasi dan memonitor TI.

Dalam mewujudkan hal tersebut PT XYZ telah menerapkan kerangka bisnis Control Objectives for Information and related $\begin{array}{llll}\text { Technology } & \text { (COBIT) } & 4.1 & \text { dalam }\end{array}$ mengembangkan pengelolaan TI di perusahaannya termasuk diseluruh wilayah asset yang ada. Namun seiring berjalannya waktu perusahaan tidak lagi melakukan evaluasi dan monitoring pada Tata Kelola TI yang diterapkan selama lebih dari 3 tahun, termasuk untuk mengevaluasi perkembangan TI 
yang semakin maju serta kebutuhan perusahaan yang berubah.

Untuk mengatasi permasalahan tersebut, maka PT XYZ perlu melakukan evaluasi Tata Kelola TI untuk mengetahui kinerja TI di perusahaan dengan menggunakan Framework COBIT 5. COBIT versi 5 ini merupakan kerangka bisnis yangmemiliki fokus tidak hanya pada fungsi TI, tetapi juga memperlakukan Informasi dan Teknologi terkait sebagai aset yang perlu ditangani sama seperti aset lainnya oleh setiap orang di perusahaan (ISACA, 2013). Dengan semakin meningkatnya persaingan serta proses bisnis yang ada dalam perusahaan, maka penting bagi PT. XYZ untuk meningkatkan nilai TI dan mengecilkan risiko yang mungkin terjadidengan melakukan upgrade penerapan Tata Kelola TI dari yang sebelumnya yaitu COBIT versi 4.1 dengan yang terbaru COBIT versi 5.

Pemilihan Framework COBIT 5 yang merupakan edisi terbaru dari COBIT Information System Audit and Control Association (ISACA) inidengan pertimbangan bahwa Framework COBIT 5 merupakan standar yang telah diakui dan diterima secara internasional, Framework ini juga direkomendasikan untuk penerapan Tata Kelola TI yang baik (ISACA, 2012). Untuk melakukan evaluasi, Framework ini menyediakan model Process Assessment Model (PAM) yaitu pengukuran untuk mengetahui kapabilitas dari proses yang telah dijalankan. Pengukuran ini sangat penting untuk mengetahui pada posisi berapakah proses tata kelola yang telah dilaksanakan berada berdasarkan COBIT 5, yang hasilnya dapat menjadi pertimbangan serta perbaikan pada Tata Kelola selanjutnya (ISACA, 2013). Dalam hal ini kerja praktik yang dilakukan bertujuan untuk mengukur tingkat kapabilitas proses Tata Kelola TI menggunakan Framework COBIT 5 dengan studi kasus PT XYZ

\section{METODOLOGI}

Metodologi yang digunakan untuk mengetahui keadaan Tata Kelola Teknologi Informasi pada perusahaan, atau kinerja Teknologi Informasi yang sedang berjalan menggunakan teori dalam Framework COBIT 5. Tahapan dalam penelitian yang dilakukan dapat digambarkan dalam flowchart pada Gambar 1 berikut ini. Dapat dilihat beberapa step/langkah dalam Goals Cascade COBIT 5 yang diantaranya adalah:

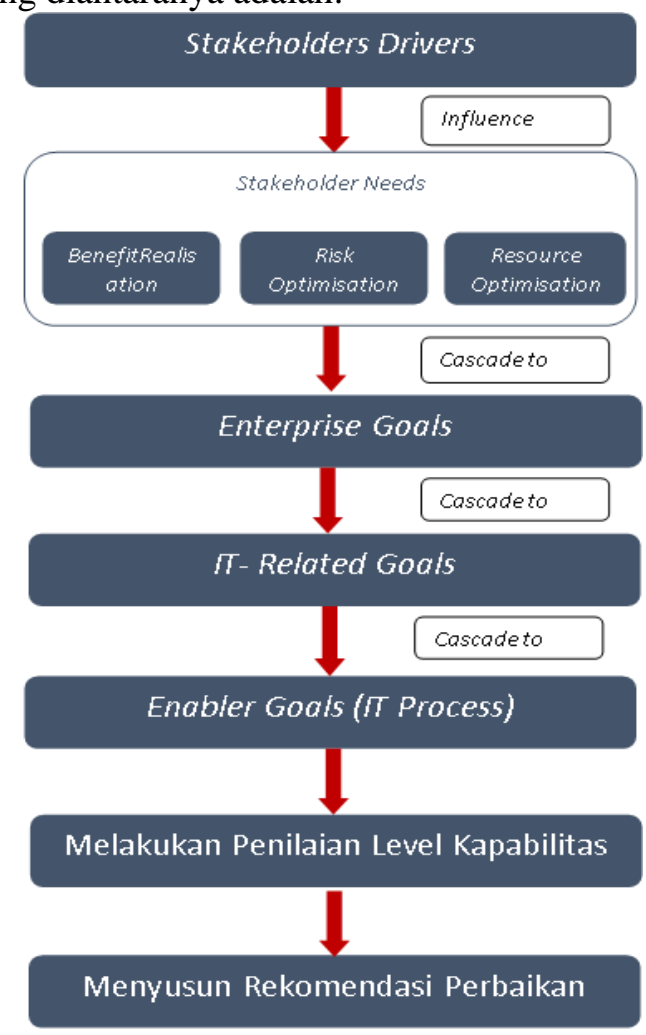

Gambar 1. Alur Metodologi

\subsection{Step 1 Stakeholder Driver}

Pada tahap ini dilakukan pengamatan dan diskusi dengan pihak di lingkungan kerja PT XYZ, untuk mengidentifikasi kebutuhan stakeholders yang dipengaruhi sejumlah driver dan pemetaan RACI Chart, antara roles di COBIT 5 dengan roles di PT XYZ. Pengamatan ini hanya dilakukan pada fungsi ICT PT XYZ, hal ini dikarenakan adanya keterbatasan lingkup Kerja Praktik, sehingga tidak memungkinan untuk dilakukannya wawancara kepada seluruh stakeholder yang disarankan oleh Framework COBIT 5.

\subsection{Step 2 Enterprise Goals}

Pada tahapan ini, dilakukan identifikasi melalui diskusi dengan Manager ICT PT XYZ mengenai sasaran umum perusahaan berdasarkan kebutuhan stakeholder. Identifikasi ini dilakukan dengan mengacu pada dokumen penilaian COBIT 4.1 yang telah dimiliki sebelumnya dengan keadaan perusahaan pada saat ini. 


\subsection{Step 3 IT related Goals}

Pada tahapan ini dilakukan pemetaan antara enterprise goals yang telah diidentifikasi sebelumnya dengan IT-related Goals COBIT 5. Dalam pemetaan ini dilakukan eliminasi beberapa IT-related Goals yang telah terpetakan, untuk dipilih satu IT-related Goals saja sebagai prioritas perusahaan dalam melakukan penelitian kali ini.

\subsection{Step 4 IT Process}

Pada tahapan ini dilakukan pemetaan antara IT-related Goals yang telah diidentifikasi sebelumnya dengan IT Process COBIT 5. Dalam pemetaan ini proses yang diambil merupakan proses yang primary dari semua domain yang ada.

\subsection{Step 5 Melakukan Penilaian Kapabilitas}

Pada tahapan ini akan dilakukan penilaian salah satu proses TI dari domain yang telah ditentukan dengan menentukan target level yang akan dicapainterlebih dahulu, melalui diskusi bersama pihak ICT PT. XYZ. Setelah itu dilakukan Process Asessment Model (PAM) pada proses yang telah dipilih yaitu dengan melakukan pengecekan Best Practices (BPs) dan Work Product (WPs).

Kemudian melakukan penilaian kapabilitas pada level 1 hingga 5 menggunakan tools Selfassessment. Langkah pertama pada pendekatan Self-assessment ini adalah Menentukan proses yang akan dinilai, kemudian menentukan kapabilitas level 1 dengan mengecek setiap kriteria yang telah disediakan pada Selfassessment worksheet COBIT 5. Kemudian menentukan apakah tingkat kapabilitas level 2 hingga 5 pada proses yang dipilih telah tercapai. Setelah mengetahui posisi level Perusahaan, maka langkah selanjutnya adalah mencatat dan merangkum level kapabilitas pada tabel assessment.

\subsection{Step 6 Menyusun rekomendasi perbaikan \\ Pada tahapan ini dilakukan penarikan} kesimpulan terhadap hasil akhir penilaian proses TI yang dilakukan beserta nilai kesenjangan tingkat kematangan dengan mengurangi tingkat kematangan yang diharapkan dengan tingkat pada saat ini dan memberikan rekomendasi untuk meminimalisir kesenjangan antara pencapaian saat ini dan target yang telah ditentukansesuai standar COBIT 5.

\section{HASIL DAN PEMBAHASAN}

Berdasarkan hasil pengamatan dan diskusi yang telah dilakkukan di lingkungan PT XYZ, diperoleh bahwa driver yang mempengaruhi kebutuhan stakeholder adalah lingkungan kerja, adanya perubahan peningkatan teknologi dan perubahan dalam proses bisnis perusahaan dan untuk melakukan evaluasi Tata Kelola TI COBIT 5 business goals yang digunakan adalah "Business Continutiy and Availibility"sesuai dengan penilaian COBIT 4.1 sebelumnya, pertimbangan menggunakan business goals tersebut adalah karena masih relevan dengan sasaran yang ingin dicapai oleh perusahaan untuk digunakan dalam tahap penentuan Enterprise Goals ini. Berdasarkan tujuan bisnis tersebut maka Tujuan TI yang terkait (ITrelated Goals ) adalah sebagai berikut :

\section{Tabel 1. IT- related Goal}

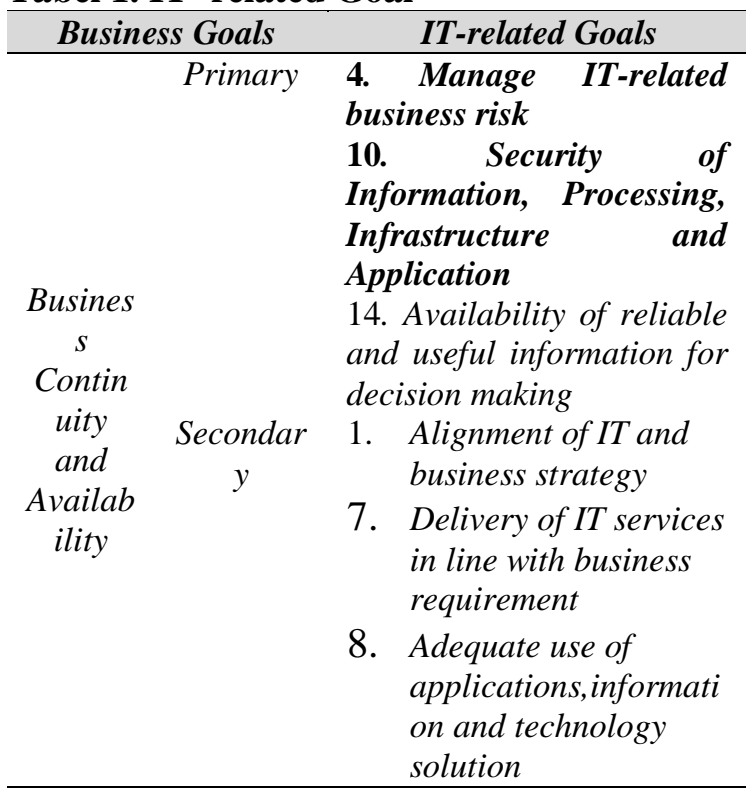

Dari hasil pemetaan yang didapatkan maka dilakukan diskusi dengan salah satu pihak perusahaan untuk memilih satu IT-related Goals yang menjadi prioritas yaitu nomor 4 . Manage IT-related business risk dan nomor 10. Security of Information, Processing, Infrastructure and Application.

Kemudian dilakukan pemetaan Enabler Goals berdasarkan Framework COBIT 5 dengan melihat proses primary dan secondary yang berkaitan dengan kedua IT-related Goals yang telah dipilih sebelumnya. Kegiatan 
pemetaan tersebut menghasilkan 55 IT-process. Dari 55 IT- process tersebut dipilihlah 1 ITprocess prioritas yang akan dilakukan penilaian/ pengukuran kapabilitasnya menggunakan metode self assessment, ITProcess tersebut adalah BAI06 Manage Changes (Mengelola Perubahan. Langkah yang pertama yang dilakukan adalah mengecek kriteria melalui Work Product (WPs) dan Best Practice (BPs) sesuai COBIT 5, pada kapabilitas level 1 maka dilanjutkan dengan pengecekan kriteria pada Generic Practice dan Generic Work Product pada COBIT 5.

Setelah dilakukannya proses pengecekan Best Practices dan Work Product untuk mengetahui kapabilitas pada level 1, maka berikut ini adalah perhitungan persentase dari total bukti ketersediaan input dan output Work Product di perusahaan yang ada di setiap tujuan,. Berdasarkan Tabel 2 jumlah Work Product yang tersedia adalah 39 input output dan Work Product yang tidak tersedia adalah 19 input output.

Tabel 2. Persentase Jumlah Work Product BAI06

\begin{tabular}{ccccc}
\hline $\begin{array}{c}\text { Outcome } \\
\text { BAI01 }\end{array}$ & $\begin{array}{c}\text { Tersedia } \\
\text { (Input/ } \\
\text { output) }\end{array}$ & $\begin{array}{c}\text { Tidak } \\
\text { Tersedia }\end{array}$ & $\begin{array}{c}\text { Jumlah } \\
\text { Total } \\
\text { Input/ } \\
\text { Output) }\end{array}$ & $\begin{array}{c}\text { \% } \\
\text { Tersedia }\end{array}$ \\
\hline BAI01-01 & 8 & 2 & 10 & $80 \%(\mathrm{~L})$ \\
BAI01-02 & 8 & 1 & 9 & $89 \%(\mathrm{~F})$ \\
BAI01-03 & 12 & 3 & 15 & $80 \%(\mathrm{~L})$ \\
BAI01-04 & 2 & 2 & 4 & $50 \%(\mathrm{~L})$ \\
BAI01-05 & 3 & 4 & 7 & $43 \%(\mathrm{P})$ \\
$\begin{array}{c}\text { BAI01-06 } \\
\text { Jumlah } \\
\text { total }\end{array}$ & 6 & 7 & 13 & $46 \%(\mathrm{P})$ \\
& $\mathbf{3 9}$ & $\mathbf{1 9}$ & $\mathbf{5 8}$ & $\mathbf{6 7 \%}$ \\
\hline
\end{tabular}

Berdasarkan hasil persentase kapabilitas yang dilakukan sebelumnya dapat dilihat bahwa kapabilitas level 1 diperoleh sebesar 67\% yang artinya pada level 1 proses BAI01 berada di posisi Largely Achieved (50\%-85\%) yang dapat dilihat pada Tabel 3. Maka dari hasil tersebut dapat dilanjutkan untuk mengukur ke level 2. Untuk melakukan penilaian pada level 2 hingga 5 maka dilakukan wawancara dengan pihak PT XYZ. Berdasarkan hasil wawancara yang dilakukan pada level 2 diperoleh hasil bahwa pada level 2 PT XYZ telah mencapai setiap kriteria yang ada.

Dalam level 2 terdapat 2 atribut yang perlu di nilai, yaitu pada PA 2.1 Manajemen Kinerja- Ukuran sejauh mana kinerja suatu proses dikelola, mencapai rating Fully Achieved dan PA 2.2 Manajemen Produk Kerja- Ukuran sejauh mana produk kerja yang dihasilkan oleh proses telah dikelola secara tepat. Produk kerja (atau output dari proses) ditentukan dan dikendalikan mencapai rating Largely Achieved

Karena telah memenuhi syarat untuk dapat dinilai ke level selanjutnya maka dilakukan penilaian pada level 3

Tabel 3 Hasil Penilaian Level 1

\begin{tabular}{|c|c|c|c|c|c|}
\hline $\begin{array}{l}\text { Atribut } \\
\text { Level } 1\end{array}$ & Kriteria & $\begin{array}{c}\text { Not } \\
\text { achieve } \\
\text { d } \\
(0-15 \%)\end{array}$ & $\begin{array}{c}\text { Partially } \\
\text { Achieve } \\
\text { d (15\% - } \\
\mathbf{5 0 \% )}\end{array}$ & $\begin{array}{c}\text { Largel } \\
\mathbf{y} \\
\text { Achiev } \\
\text { ed } \\
(50 \% \text { - } \\
\mathbf{8 5 \%}) \\
\end{array}$ & $\begin{array}{c}\text { Fully } \\
\text { Achieve } \\
\text { d (85- } \\
100 \%)\end{array}$ \\
\hline \multirow[t]{7}{*}{$\begin{array}{l}\text { Level } 1 \\
\text { Perfor } \\
\text { med/ } \\
\text { Telah } \\
\text { Dilakuk } \\
\text { an }\end{array}$} & $\begin{array}{l}\text { Hasil } \\
\text { proses } \\
\text { berikut } \\
\text { ini } \\
\text { sedang } \\
\text { dicapai: }\end{array}$ & & & $\mathbf{L}$ & \\
\hline & $\begin{array}{l}\text { BAI01- } \\
\text { O1 }\end{array}$ & & & & F \\
\hline & $\begin{array}{l}\text { BAI01- } \\
\text { O2 }\end{array}$ & & & & F \\
\hline & $\begin{array}{l}\text { BAI01- } \\
\text { O3 }\end{array}$ & & & $\mathrm{L}$ & \\
\hline & $\begin{array}{l}\text { BAI01- } \\
04\end{array}$ & & & $\mathrm{~L}$ & \\
\hline & $\begin{array}{l}\text { BAI01- } \\
\text { O5 }\end{array}$ & & $\mathrm{P}$ & & \\
\hline & $\begin{array}{l}\text { BAI01- } \\
\text { O6 }\end{array}$ & & $\mathrm{P}$ & & \\
\hline
\end{tabular}

. Pada level 3 terdapat 2 atribut yang dinilai yaitu PA 3.1 Definisi proses- Ukuran sejauh mana proses standar dipertahankan untuk mendukung penyebaran proses yang ditentukan PA 3.2 Proses Deployment - Ukuran sejauh mana proses standar secara efektif digunakan sebagai proses yang ditentukan untuk mencapai hasil prosesnya.

Tabel 4 Rangkuman Hasil Tingkat Kapabilitas BAI06

\begin{tabular}{|c|c|c|c|c|c|c|c|c|}
\hline \multirow{2}{*}{$\begin{array}{l}\text { Proce } \\
\text { ss } \\
\text { Name } \\
\text { BAI0 }\end{array}$} & \multirow{2}{*}{$\begin{array}{l}\text { Leve } \\
10\end{array}$} & $\begin{array}{l}\text { Leve } \\
11\end{array}$ & \multicolumn{2}{|l|}{ Level 2} & \multicolumn{2}{|c|}{ Level 3} & \multicolumn{2}{|c|}{ Level 4} \\
\hline & & $\mathrm{PA}$ & $\mathrm{PA}$ & $\mathrm{PA}$ & $\mathrm{PA}$ & $\mathrm{PA}$ & PA & PA \\
\hline 1 & & 1.1 & 2.1 & 2.2 & 3.1 & 3.2 & 4.1 & 4.2 \\
\hline $\begin{array}{l}\text { Ratin } \\
\text { g by } \\
\text { Crite } \\
\text { ria }\end{array}$ & $\mathbf{F}$ & $\mathbf{L}$ & $\mathbf{F}$ & $\mathbf{F}$ & $\mathbf{N}$ & & & \\
\hline $\begin{array}{l}\text { Capa } \\
\text { bility } \\
\text { Level } \\
\text { Achie } \\
\text { ved }\end{array}$ & & & & 2 & & & & \\
\hline
\end{tabular}


Berdasarkan wawancara yang di lakukan diperoleh hasil bahwa PT XYZ belum mencapai setiap kriteria pada level 3 tersebut (rating Not Achieved). Oleh karena itu penilaian tidak dapat dilakukan ke level selanjutnya. Hasil dari penilaian pada Generic Practice dan Generic Work Product pada level diatas kemudian di catat dan diringkas pada Tabel 4 diatas.

Berdasarkan Self-assessment yang telah dilakukan, didapatkan hasil bahwa pada proses BAI01 Manage programme and project, PT. XYZ berada pada posisi level 2 (managed process) yaitu tingkatan dimana proses yang dilakukan sekarang telah diimplementasikan secara terkelola (mencakup perencanaan, monitor, dan penyesuaian) dan Work Productnyatelah dijalankan, dikendalikan dan dipelihara dengan tepat. Berdasarkan tingkat kematangan pada saat ini (as is) dan tingkat kematangan yang diharapkan yaitu berada pada level 3 (satu tingkat diatas tingkat pada saat ini), maka diperoleh nilai kesenjangan (gap) pada tingkat kematangan adalah sebesar 1 tingkat.

Rekomendasi Perbaikan yang dapat diberikan diantaranya adalah 2. Untuk

meningkatkan level maturity pada proses BAI01 Mengelola Program dan Proyek menjadi level 3 dan memenuhi gap yang ada makasaran yang dapat diberikan adalah

a. Membuat Standard Operation Procedure (SOP) Manajemen Program dan Proyek yang mencakup siklus hidup penuh dan disiplin yang harus diikuti, termasuk pengelolaan ruang lingkup, sumber daya, risiko, biaya, kualitas, waktu, komunikasi, keterlibatan pemangku kepentingan, pengadaan, kontrol perubahan, integrasi, dan realisasi manfaat

b. Membuat SOP Monitor and Control untuk Program dan Proyek TI untuk mengukur kriteria kinerja proyek seperti jadwal, kualitas, biaya dan risiko beserta laporan kinerja proyek dan peninjauan stage gate.

c. Membuat SOP Risiko Program dan Proyek TI, untuk mengidentifikasi, menganalisis, menanggapi, memitigasi, memantau, dan mengendalikan risiko.

d. Melakukan peninjauan dan evaluasi terhadap pelaksanaan proses sesuai dengan SOP yang telah dibuat.

\section{KESIMPULAN}

Berdasarkan hasil evaluasi Tata Kelola TI yang dilakukan di ICT PT XYZ pada proses domain BAI01 Mengelola Program dan Proyek, didapatkan kesimpulan sebagai berikut:

1. Enterprise Goals dari PT XYZ adalah Business Continutiy and Availibility

2. IT-related Goals dari PT XYZ Asset 5 adalah Manage IT-related business risk dan Security of Information, Processing, Infrastructure and Application.

3. Enabler process yang didapatkan dari hasil pemetaan dengan IT-related Goals adalah domain Evaluate, Direct, Monitor (EDM) proses EDM03 Memastikan Optimalisasi Risiko, domain Align, Plan, and Organize (APO) proses APO10 Mengelola Pemasok, APO12 Mengelola Risiko, APO13 Mengelola Keamanan dan domain Build, Acquire and Implement (BAI) proses BAI01 Mengelola Program dan Proyek dan BAI06 Mengelola perubahan.

4. Berdasarkan Self-assessment yang telah dilakukan, didapatkan hasil bahwa pada proses BAI01 Manage programme and project, PT. XYZ berada pada posisi level 2 (managed process) yaitu tingkatan dimana proses yang dilakukan sekarang telah diimplementasikan secara terkelola (mencakup perencanaan, monitor, dan penyesuaian) dan Work Product-nya telah dijalankan, dikendalikan serta dipelihara dengan tepat.

\section{DAFTAR PUSTAKA}

Chondro, D. (2013). Penilaian penerapan teknologi informasi menggunakan Framework COBIT 5 di Institut Teknologi Telkom. Penilaian penerapan Teknologi Informasi , 3-4.

ISACA. (2012). COBIT 5 : Enabling Processes. USA: ISACA. ISACA.

ISACA. (2013). COBIT 5: IT Governance Institute. United States of America.

ISACA. (2013). COBIT 5 for Risk. USA: ISACA.

ISACA. (2012). COBIT 5: A Business Framework for the Governance and Management of Enterprise IT. USA: ISACA.

ISACA. (2010). IT Standards, Guidelines, Tools and Techniques for Audit and Assurance and Control Professionals. ISACA. 
ISACA. (2013). Process Assessment Model (PAM): Using COBIT 5. USA: ISACA.

ISACA. (2013). Self-assesment Guide: Using COBIT 5. USA.

ITGI. (2003). Board Briefing on IT Gorvenance. USA: IT Governance Institute.

Lutfi Rinanty, N. (2017). Analisis dan Perancangan Tata Kelola Teknologi Informasi pada Lembaga Keuangan Mikro Menggunakan Framework COBIT 5 Domain Build, Acquire, and Implement (BAI). e-Proceeding of Engineering , 3042. 